\title{
A Development of Foreign Language Training Course for Local Youth Guides of Dankwian Community in Thailand
}

Pitchayapa Chavangklang*, Thanaset Chavangklang

Business English Department, Nakhon Ratchasima Rajabhat University, 340 Suranarai Rd. Muang District, Nakhon Ratchasima 30000 , Thailand

Corresponding Author: Pitchayapa Chavangklang, E-mail: cpitchayapa9@gmail.com

\section{ARTICLE INFO}

Article history

Received: March 02, 2018

Accepted: April 08, 2018

Published: July 06, 2018

Volume: 9 Issue: 4

Advance access: August 31, 2018

Conflicts of interest: None

Funding: The research is financed by the Faculty of Humanities and Social Sciences, Nakhon Ratchasima Rajabhat University

\author{
Key words: \\ Foreign Language, \\ English Language, \\ Training Course, \\ Curriculum Development, \\ Local Youth Guide, \\ Local Tourism
}

\begin{abstract}
English language has become increasingly more important as it is used as an international language to communicate with people from other countries, especially in the tourism, which is one of Thailand's most growing industrial sectors today. Although English is taught at all educational levels in Thailand for general purposes, there is still need for specific use of English in some areas such as local tourism places. This leads to the need for improving the English language ability of people in such areas, particularly young people, who are most likely to have influential effects not only on themselves but also their families and community as a whole. The objective of this study was to develop and evaluate a foreign language training course for Local Youth Guide at Dankwian Community - a famous pottery-making village in Thailand. The course was developed in four stages: 1) Studying background information; 2) Developing the training course of Foreign Language for Local Youth Guide; 3) Trying-out the course; and 4) Evaluating the course. The training course was implemented with a group of 60 junior high school students. The study was designed for one group pretest-posttest, using pre-post tests and a satisfaction questionnaire as study tools. The study revealed the following results. 1) The community members needed a foreign language training course which has both lecturing and workshops. 2) The course consisted of one ice-breaking module and five language modules. 3) While attending the course, participants were enthusiastic, asking questions, and actively contributing to the discussions. 4) After the course, participants significantly improved their language ability at the. 05 level. The participants' satisfaction on the training course was at the 'very high' level. They indicated that the course emphasized on the real life applications. These results revealed the usefulness of a short training course for local youth guides in Thailand. It can be applied to other local areas in Thailand that have foreign tourists. A similar training course can be developed by making some modifications to this course to fit their local contents.
\end{abstract}

\section{INTRODUCTION}

\section{Background to the Study}

The Tourism Authority of Thailand (TAT) has launched a "Discover Thainess" campaign since 2015, and the campaign is still in effect until now. The word Thainess refers to Thai culture which includes people, traditions, customs, life styles, architecture, nature, language, dressing, and so on, inherited from generation to generation, or adapted to suit current life styles, which may be in traditional or contemporary forms.

Thailand has a variety of tourism resources such as the natural beauty, cultural and historical heritage, through to the Thai ways of living, as is currently seen on the campaign. Tourism plays a vital role in the country's economic and social development because it creates numerous related service industries which distribute incomes into societies and communities. In Thailand, tourism industry is considered a major tool for earning national income which can be contributed to all local areas of the country through the creation of tourism-related jobs. Local tour guiding is among the jobs which can be developed for local people so as to enhance their standards of knowledge, responsibility, as well as communication skills using English as a medium. Through this development, local people can improve their potential and participate in tourism activities of the community.

\section{Rational of the Study}

For local areas where tourism is a major source of income, people need to use English not only for general communication, but for their career. However, in the current time, it has been found that people in these areas cannot communicate in English effectively, especially among adults, as English is used as a foreign language in Thailand. In the same way, young people have the chance to learn many subjects in English in school. These subjects bring the learners up to the ability which is not adequate to communicate in everyday 
life effectively, not to mention the use for such contexts as being a tour guide. This leads to the need for developing a course for local tour guides especially the young people in order to improve their ability of using English for communication in various situations related to the work of a tour guide in the local area. Such training courses have to suit people in different areas and must be flexible accordingly (Academic Department, 1990: 23). In a field visit in January 2016 at Ban Dankwian community, which is one of the local tourism areas, best-known as the pottery village in Nakhon Ratchasima Province in Thailand, the researchers talked to local business owners, teachers, and people in the community. It was found that tourists who come to this village included both Thais and foreigners. One of the major concerns the community had was that local business owners could not communicate with foreign tourist clearly, which resulted in low chance of selling or promoting their products.

\section{Research Problem}

After the interviews with stake holders in the local community at Ban Dankwian community, the problems they had were that they could not explain to the foreigners the details of their products other than telling prices. In order to improve their English, there had been attempts from local government and educational institutes to provide English training courses. However, local entrepreneurs were usually not able to attend those courses due to the time constraints. With this latest attempt, when a local guide training course was offered, they recommended that, to be more beneficial, the participants should be young people at their local school, rather than adults. After some meetings at Dankwian Wittaya School, teachers and administrators agreed to have a training course at the school for junior high school level. The researchers, therefore, responded to the needs by developing a training course for young local guides, focusing on the contexts of the pottery village of Ban Dankwian. This study reports on the development of the course and the evaluation of its implementation.

\section{Objectives of the Study}

The aims of the study were: 1) to develop a foreign language training course for Local Youth Guide at Dankwian Community; and 2) to evaluate a foreign language training course for Local Youth Guide at Dankwian Community.

\section{Sample of the Study}

The research population included Grade 8 junior high school students at Dankwian Wittaya School, Nakhon Racthasima, Thailand. The research samples were 60 Grade 8 junior high school students at Dankwian Wittaya School, Nakhon Racthasima, Thailand, selected by using the purposive sampling method on a voluntary basis.

\section{The Significance of the Study}

This study is significant in two ways. Firstly, the training course developed in this study can be a model for developing other courses which aim at improving English language ability of people in the local tourism areas, through young people. This course can be directly taken for other target areas or modified to suit educational and pedagogical contexts. Secondly, students who participated in the training improved their English language ability which can further affect their parents. As a whole, the study has put some light to the community in finding ways in improving English communication skills essential to their careers.

\section{LITERATURE REVIEW}

\section{Elements and Characteristics of a Good Curriculum}

The term "curriculum" has different meanings in different context in which it is being used. Curriculum is a medium or method which leads the learners to the end destination. Such definition of a curriculum has been given by Taba (1962). Sayler and Alexander (1974: 3) stated that a curriculum refers to all attempts of the school in making desirable learning outcomes at the school, both inside and outside school conditions. However, Beauchamp (1981) has identified three types of curriculum

1. A curriculum refers to a document created as guidelines for educational management, consisting of details about organizing learning experiences for learners, curriculum goals, contents, instructional activities, as well as testing and evaluation.

2. A curriculum refers to an operational system about the curriculum, consisting of advanced educational curriculum development.

3. A curriculum refers to an educational field - a definition used in higher level educational institutes.

Taba (1962: 11) suggested a concept about elements of a curriculum, which should be the following:

1. General and subject-specific objectives

2. Subject contents

3. Instructional process

4. Instructional evaluation structure according to the curriculum

\section{Curriculum Development Planning}

1. Diagnosis of needs. The investigation of needs is the most important in the planning process. Curriculum developers (teachers) have to diagnose the learners' experiences, needs, and interests and use them to determine the curriculum contents.

2. Formulation of objectives. When the needs of the learners or the society have been identified, curriculum developers develop objectives for the curriculum, which will determine the specifications of the contents and methods for organizing learning experiences.

3. Selection of content. Curriculum developers select contents to be delivered to the learners by considering the content validity according to the objectives and significance of the contents to the learners.

4. Organization of content. The selected contents need to be put in sequences using certain criteria or system. 
Developers should also consider links and focuses of the contents to the objectives and levels of learners.

5. Selection of learning experiences. Developers should consider the order of experiences and instructional methods for developing experiences about contents and objectives.

6. Organization of learning experiences. In organizing learning experiences, curriculum developers should consider an important teaching strategy which is the strategic concept attainment, as well as some major questions like "How to make the content relevant to the leaners' experiences and interest?" and "How to make the learning experiences relate to and serve personal differences.

7. Determination of what to evaluate and of the ways and means of doing it. The developers should evaluate the learning outcomes of the learners according to the curriculum objectives by answering the questions of how to evaluate the quality of learning and by what evaluation tools and methods.

Based on the curriculum development process of Taba, the importance is put on the fact that the curriculum developers should be the teachers. In other words, the curriculum should be developed by the users. This seven-step curriculum development is known as the grass-roots model.

From the concept of educators about curriculum development, it can be seen that the curriculum development can be both the improvement of an existing one or the creation of a new one. The development process is a system which links to various dimensions such as planning and drafting, implementing, and evaluating the curriculum. The current study employed the curriculum development concepts based on Taba (1962).

\section{RESEARCH METHODOLOGY}

\section{Research Design}

This experimental study was designed to have a targeted group of participants take a pretest and a posttest when they participated in the training course, which was developed according to the 4-step process of Taba (1962). The design is: $\mathrm{O} 1 \mathrm{X} \mathrm{O} 2$

\section{Research Tools}

There were two research tools in this study. The experimental tool was the Foreign Language Training Course for Local Youth Guides. Data collection tools included: 1) The achievement tests for the Foreign Language Training Course for Local Youth Guides; and 2) The questionnaire on the satisfaction on the Foreign Language Training Course for Local Youth Guides.

\section{Development of the Research Tools}

The Foreign Language Training Course for Local Youth Guides was developed according to the Taba' guidelines (1962) which consists of four steps as follows.
Step 1: Diagnosing needs

In this step, the researcher surveyed the needs and interests of the learners in order to determine the course contents. The questionnaires were administered to 10 administrators and teachers, 10 local entrepreneurs, 10 community leaders and parents, and 20 students, with the total of 50 respondents. Step 2: The development and evaluation of the course

The development and evaluation of the training course followed these procedures.

1. Formulating course objectives based on the need survey results in Step 1.

1.1 Using survey results from Step 1 to determine the course' elements.

1.2 Analyzing and synthesizing stages of training activities from documents and related research studies.

1.3 Drafting the foreign language training course for local youth guides.

1.4 Developing training manuals, consisting of: 1) descriptions of course elements; 2) training plans; and 3) training documents.

2. Evaluating the training course

2.1 Experts evaluated the training course, the pretest/ posttest, and training manual. The corrections were made accordingly.

2.2 The course was tried out with a group of 10 students of different language ability ( 3 low, 4 moderate, and 3 high). The results were recorded as to what to be improved before the actual implementation of the course.

Step 3: Implementing the course.

The training course was implemented with the target group of 60 students in semester 2 of the academic year 2017.

1. Recruited students on a voluntary basis who want to participate in the study during November 2017.

2. Informed the training schedule and procedures to the students; which consist of orientation, pretest, training, and posttest, and the course would take 2 days.

3. Made the training preparation: staff, teaching media, and facilities.

4. Implement the training course as planned.

Step 4: Evaluating the course

1. The course was evaluated using a pretest and a posttest. The tests consisted of two parts. Part 1 contained 30 multiple choice items, which were selected from the total of 40 items ( 8 items from 5 topics). Part 2 included 10 questions on self-introduction.

2. The participation's satisfaction on the training course was evaluated using a satisfaction questionnaire.

\section{Data Analysis}

The data received from the tests and the questionnaires were analyzed using the average percentage of the score and the statistics.

\section{Statistics used for evaluating the tools' quality}

The quality of the research tools were evaluated by investigating the content reliability, represented in the item-objective congruency. 


\section{Statics Used for Testing Hypothesis}

1. The comparison between the pretest and the posttest scores was analyzed by the dependent sample t-test analysis (Educational Evaluation Group, 2013: 163).

2. Means and standard deviations are used to assess the participants' satisfaction on the training course.

\section{RESULTS}

The results of the study are summarized below.

1. The need assessment showed that, the 50 respondents of the survey reported their needs for developing a training course on local youth guide at Dankwian community at the "high" level in all issues, including the contents on introducing the pottery production process and learning activities that involve role-plays of selling products and other language usage for tour guiding. The training should be in the form of a short course. Additionally, the course administration should be the responsibility of the school and the community. Finally, the course evaluation tools were the pretest and the posttest as well as questionnaires.

2. The training course for local youth guides at Dankwian Community was in line with the need of the community and the concept of Taba (1962) which suggests four main elements to include in the course: objective, content, activity, and evaluation. The development process of the course covered three stages of: 1) exploring basic information from documents and related studies; 2) investigating problems and basic requirements of the course; and 3) using and evaluating the course. The course developed for this study consists of six modules.

Module 1 Group Relation

Module 2 Introduction to Tour Guiding

Module 3 Welcoming Visitors

Module 4 Introducing the Local Community

Module 5 Introducing Local Products

Module 6 Bidding Farewell

3. During the training, which was the step of implementing the course, at Dankwian Wittaya School, Chok Chai district, Nakhon Ratchasima, 60 students participated during a two-day training period from 29-30 November, 2017. All the participants were enthusiastic with the training, asking questions, and participated every module of the course. Activities ranged from short lecturing, demonstration, and practicing skills for being a local tour guide.

4. The course was evaluated by two means: the assessment of the ability in using English for local youth guide and participants' satisfaction.

1. The pretest and posttest results revealed that the students who participated gained significantly higher scores of the posttest than the pretest at the 0.05 significance level. The results are shown in Table 1.

2. The questionnaire results showed that participants reported their satisfaction on the training courses at "very high' levels, as shown in Table 2. The highest satisfaction was on Module 6 Bidding Farewell, while the lowest was on Module 2 Introduction to Tour Guiding.
The overall satisfaction of the course was at 'very high' level on three issues (contents, trainers, and learning activities), while the issue on media and tools received the satisfaction at 'high' level. The results are illustrated in Table 3.

\section{DISCUSSION}

In the development and evaluation of a training course for local youth guides at Dankwian Community, Chok Chai, Nakhon Ratchasima, results are discussed as follows.

In Step 1 of the study, needs assessment from 50 people of different career groups in the community reported their needs for developing a course for local guides. The scores of their needs were at 'high' levels in all aspects. They agreed with the objectives, the contents, the activities, and the evaluation format, and suggested that the course should be in the form of short-term training focusing on high school students. Therefore, the course should be co-organized by the school and the community. The course development process of the study was supported by Wither (2000) who recommends that a local training course should be consistent with the local context, by which students are appropriate target groups as they the most enthusiastic among local people. The results are also in line with Choochat (2001) who supported the contribution of the community in managing local tourism.

The training course was designed to consist of objectives, contents, activities, and evaluation based on the concept of Taba (1962: 10). The development process covered the stages of investigating basic information from documents and relevant studies, exploring states of problem and the development of the course structure, and evaluating the course. The training format of the present study consisted of teaching vocabulary, pronunciation practice, pattern of useful sentences, conversation through activities that are similar to Sukakoon et al. (2005) study. The process of this study was also in line with Jaroentasanasiri (2005), Sriklinto (2006), and Srisattarattanamat (2008) which consisted of four steps; 1) study background information 2) development of the training course 3) using the course and 4) evaluating the course by using One Group Pretest - Posttest Design.

In the implementation step of the course, the 60 students were trained by use of various activities throughout the two days of training. Also, the contents of the training course of the present study were developed using the functional approach which suggested by Sriklinto (2006) and the course was trained by having the following topics; asking and offering helps, giving direction, and explaining tourist attractions. The participants showed their enthusiasm while doing the course activities both in the lecturing and practicing modes. They learned how to improve their skills especially speaking, as well as other skills essential for being a local tour guide. The results of this study were supported by Jaroentasanasiri (2005), Sriklinto (2006), and Srisattarattanamat (2008). In the study of Srisattarattnanmat (2008), the course was implemented for three days, focusing on Eco tourism around Kangkrajan National Park, covering contents on a wide range of vocabulary. The current study employed two days of course implementation. This is because the present 
Table 1. The comparison of learning achievement before and after taking the Foreign Language training course for local youth guides

\begin{tabular}{|c|c|c|c|c|c|c|c|c|c|c|c|}
\hline \multirow[t]{2}{*}{ Tests } & \multirow[t]{2}{*}{ Score } & \multicolumn{4}{|c|}{ Pretest score } & \multicolumn{4}{|c|}{ Posttest score } & \multirow[t]{2}{*}{ t-test } & \multirow[t]{2}{*}{$\mathbf{P}$} \\
\hline & & Min & Max & Mean & S.D. & Min & Max & Mean & S.D. & & \\
\hline $\begin{array}{l}\text { The ability of using } \\
\text { English for local guides }\end{array}$ & 40 & 16 & 29 & 21.87 & 2.70 & 20 & 35 & 27.65 & 3.78 & 1.671 & $<0.01$ \\
\hline
\end{tabular}

Table 2. Participants' satisfaction on the Foreign Language Training Course for Local Youth Guides

\begin{tabular}{|c|c|c|c|}
\hline Issues & Mean & S.D. & $\begin{array}{l}\text { Satisfaction } \\
\text { level }\end{array}$ \\
\hline 1. Knowledge about English for local youth guides before training & 3.43 & 1.03 & Moderate \\
\hline 2. Knowledge about English for local youth guides after training & 4.25 & 0.60 & High \\
\hline 3. Usefulness of the training course for local youth guides for the participants and their families & 4.25 & 0.63 & High \\
\hline 4. Topic 1 Group relationship & 4.49 & 0.59 & High \\
\hline 5. Topic 2 Introduction to Guiding & 4.48 & 0.59 & High \\
\hline 6. Topic 3 Welcoming Visitors & 4.54 & 0.56 & Very high \\
\hline 7. Topic 4 Introducing the Local Community & 4.50 & 0.61 & Very high \\
\hline 8. Topic 5 Introducing Local Products & 4.54 & 0.58 & Veryhigh \\
\hline 9. Topic 6 Bidding Farewell & 4.59 & 0.56 & Very high \\
\hline 10. Training duration and places & 4.55 & 0.67 & Very high \\
\hline Total & 4.51 & 0.59 & Very high \\
\hline
\end{tabular}

Table 3. Satisfaction on the contents, the speakers, learning activities, and the media and tools

\begin{tabular}{lccc}
\hline Issues & Mean & S.D. & Satisfaction level \\
\hline Contents & 4.52 & 0.61 & Very high \\
Trainers & 4.54 & 0.57 & Very high \\
Learning activities & 4.58 & 0.54 & Very high \\
Media and tools & 4.44 & 0.59 & High \\
Total & 4.52 & 0.58 & Very high \\
\hline
\end{tabular}

study covered a smaller area. Therefore, a two-day course might be appropriated for this training.

In the evaluation step, the course was found to be effective by the comparison of the pretest and posttest scores. Students improved their scores significantly after taking the course. Additionally, they showed their satisfaction on the course at the 'very high' levels at most of the course elements. Similar results were found in the studies of Jaroentasanasiri (2005), Sritoklin (2006), and Srisattarattanamat (2008)

\section{RECOMMENDATIONS AND LIMITATIONS}

\section{Recommendations}

With regard to the results of this study, the researchers give the following recommendations.

\section{Recommendations for using the course}

1. For the effective implementation, the results from this study suggest that a course should be divided into modules, and the number of 12 students in each group were convenient to manage in terms learning and practicing time.

2. Role-play should be used in learning activities, as Module 6 , which used role-play activities, received the highest satisfaction.

3. The course should contain less learning contents. Students' satisfaction on Module 2, which contained long contents, the lowest of all modules.

\section{Recommendations for future studies}

1. There need to be follow-up studies in order to evaluate the effect of the training course at different times and situations.

2. There should be studies which compare the language ability of different groups, e.g. the low, moderate, and high proficiency groups.

\section{Limitations of the Study}

1. Learning achievement from this course was measured by the researcher's developed pretest and posttest. Results may differ with other types of achievement measuring instruments.

2. The researchers of this study conducted the research and monitor the pre-course training, with support from teachers at the English department of Ban Dankwian Wittaya School. Apart from the researchers, the trainers in this study were also fourth year students in the Business English department who were taking the English for Outbound Tourism and English for Eco and agriculture courses. Although they were trained how to 
perform the course activities, the results would be different if the course was taught by professional trainers.

3. The participants of this study were of mixed ability, and their ability was identified according the high or the low group. Therefore, better claims may be identified if the study was designed to investigate the achievement according to the participants' ability.

\section{CONCLUSION}

This study, a development of foreign language training course for local youth guides of Dankwian Community in Thailand, is a research and development work which consists of four steps of research: need diagnosis, development, implementation, and evaluation. The objective of the study was to develop, implement, and evaluate a training course for youth local guides at Dankwian Community. The researchers developed the course and implemented it with a group of 60 Grade 8 students at Dankwian Wittaya School, Chok Chai district, Nakhon Ratchasima.

The researchers collected all the data about language ability and opinions about the course and analyzed for mean (X) and standard deviation (S.D.) and made comparison of pretest and posttest scores as to investigate improvement in the language ability using independent-sample t-test. The results revealed the following findings.

1. The study of the background information for developing a youth guide training course at Dankwian community revealed that school administrators, teachers, students, and local entrepreneurs all needed to have a youth guide training course which consisted of content about the presentation of pottery using role-play activities, selling, and using English for tour guides. The training should be in the form of a short course that contains group relation activities, presentation practices, and the course needs to be co-organized by the community and the school. Additionally, course achievement should be evaluated using pretest and posttest and questionnaire.

2. The training course for local youth guides was developed based-on the local needs as well as the concept of Tabal (1962), who suggested four parts in a curricula (objective, content, instructional activity, and evaluation). The course development steps included information investigation, studies of problems and needs, and course development and evaluation. The course was developed to contain six modules.

3. The course was implemented with a group of 60 grade nine students, who participated in the training with interests, enthusiastically engaged in the activities, asking questions while attending lectures and doing practices. This resulted in students' development of some skills in English speaking and local guide.
4. The course evaluation showed that students improved their knowledge as indicated by the posttest scores which were significantly higher than the pretest scores. Moreover, questionnaire results were that participants reported their satisfaction on the course at very high level, with the highest score on learning activity, and the lowest score on media and tools. Module 6, Bidding Farewell was the most satisfied, while Module 2, Introduction to Tour Guides, was the least. Evaluation results suggest that the training course was useful for the participants, which would in turn improve the community. Participants also expressed high level of satisfaction on the course and suggested that such courses be held continuously.

In conclusion, this study revealed that the foreign language training course for Local Youth Guides at Dankwian Community was successfully developed and implemented with the students at Dankwian Community. The use of the course improved both students' language achievement and satisfaction. On the overall, study results suggested that this training course can be used as a model for developing similar types of courses which aimed at improving English in local tourism areas with similar contexts.

\section{REFERENCES}

Academic Department (2013). Learning Development Research according to the Basic Education. Bangkok: n. p.

Beauchamp, G. A. (1981). Curriculum theory (4 $4^{\text {th }}$ ed.). Itasca, IL: F.E. Peacock.

Chuchat, C. (2001). Tourism Industry. Chiang Mai: Lanna Printing Chiangmai.

Jaroentasanasiri, R. (2003). The development of the English teacher training program for the English project work course at the secondary level for teachers, Muangsing consortrium, Kanchanaburi. MA Thesis, Silapakorn University.

Saylor, J.G. and Alexander W.M.(1974).Planning Curriculum for Schools. New York: Holt Rinehart and Winston.

Srisattarattanamat, S. (2008). The development and implementation of an environmental education training curriculum for young tourist guides on ecotourism in Kaeng krachan NationalPpark. MA Thesis, Mahidol University. Bangkok.

Sriklinto, K. (2006). The development of training program on English for tourism for local police in Phetchaburi province. MA Thesis, Silapakorn University. Nonthaburi.

Taba, H. (1962). Curriculum Development: Theory and Practice. New York: Harcourt Brace and World Inc.

Wither, S. E. (2000). Local Curriculum Development and Place - based Education. [Online]. Accessed 31 October 2016. Available from http://thailis. Uni.net.th/dao/ detail.ns.p. 